\title{
Factor analysis of rock, soil and water geochemical data from Salem magnesite mines and surrounding area, Salem, southern India
}

\author{
M. Satyanarayanan ${ }^{1} \cdot$ S. Eswaramoorthi ${ }^{2} \cdot$ S. Subramanian ${ }^{3} \cdot$ P. Periakali $^{4}$
}

Received: 7 December 2015/Accepted: 31 March 2016/Published online: 16 April 2016

(C) The Author(s) 2016. This article is published with open access at Springerlink.com

\begin{abstract}
Geochemical analytical data of 15 representative rock samples, 34 soil samples and 55 groundwater samples collected from Salem magnesite mines and surrounding area in Salem, southern India, were subjected to R-mode factor analysis. A maximum of three factors account for $93.8 \%$ variance in rock data, six factors for $84 \%$ variance in soil data, five factors for $71.2 \%$ in groundwater data during summer and six factors for $73.7 \%$ during winter. Total dissolved solids are predominantly contributed by $\mathrm{Mg}, \mathrm{Na}, \mathrm{Cl}$ and $\mathrm{SO}_{4}$ ions in both seasons and are derived from the country rock and mining waste by dissolution of minerals like magnesite, gypsum, halite. The results also show that groundwater is enriched in considerable amount of minor and trace elements $(\mathrm{Fe}$, $\mathrm{Mn}, \mathrm{Ni}, \mathrm{Cr}$ and $\mathrm{Co}$ ). Nickel, chromium and cobalt in groundwater and soil are derived from leaching of huge mine dumps deposited by selective magnesite mining activity. The factor analysis on trivalent, hexavalent and total $\mathrm{Cr}$ in groundwater indicates that most of the $\mathrm{Cr}$ in summer is trivalent and in winter hexavalent. The gradational decrease in topographical elevation from northern mine area to the southern residential area, combined regional hydrogeological factors and distribution of ultramafic rocks in the northern part of the study area indicate
\end{abstract}

M. Satyanarayanan

icpmsnarayanan@gmail.com

1 CSIR-National Geophysical Research Institute, Hyderabad 500007, India

2 Curtin University, CDT 250, 98009 Miri, Sarawak, Malaysia

3 CGWB, South East Coastal Region, Chennai 600090, India

4 Department of Applied Geology, University of Madras, Chennai 600025, India that these toxic trace elements in water were derived from mine dumps.

Keywords Groundwater $\cdot$ Geochemical data $\cdot$ Statistical analysis $\cdot$ Salem $\cdot$ Tamil Nadu

\section{Introduction}

Environmental data are strongly characterized by inherent variability, and only limited understanding of the environmental distribution of contaminants can be gained from chemical analysis (Agterberg 1974; Davis 2002; Steube et al. 2009; Machiwal and Jha 2015). Hence, statistical techniques are applied to analyse the data and infer the underlying principle/mechanism involved (Einax et al. 1997; Krishna et al. 2009; Li and Zhang 2010; Tao et al. 2014). Naturally occurring major, minor and trace elements in groundwater can have a significant effect on human and animal health through either deficiency or toxicity due to excessive intake (Frengstad et al. 2001). In India, these issues are widely discussed, out of which most researchers work on arsenic, fluoride and chromium, and other heavy metals contamination in groundwater due to its capability to affect human health and vulnerability of groundwater to change (Godgul and Sahu 1995; Dhakate et al. 2008; Kar et al. 2008; Dhal et al. 2011; Kumar 2014). Several international authors have also discussed in detail on the potential health impact due to release and transport of toxic metals in water (Edmunds and Smedley 1996; Reimann and de Caritat 1998; Frengstad et al. 2001; Cooper 2002; Moncur et al. 2005; Michael 2013; Lado et al. 2013).

The study area (Fig. 1) in and around Salem magnesite mine covers $193 \mathrm{~km}^{2}$ and is the second largest magnesite mine in India. The rock types in the study area are basic 


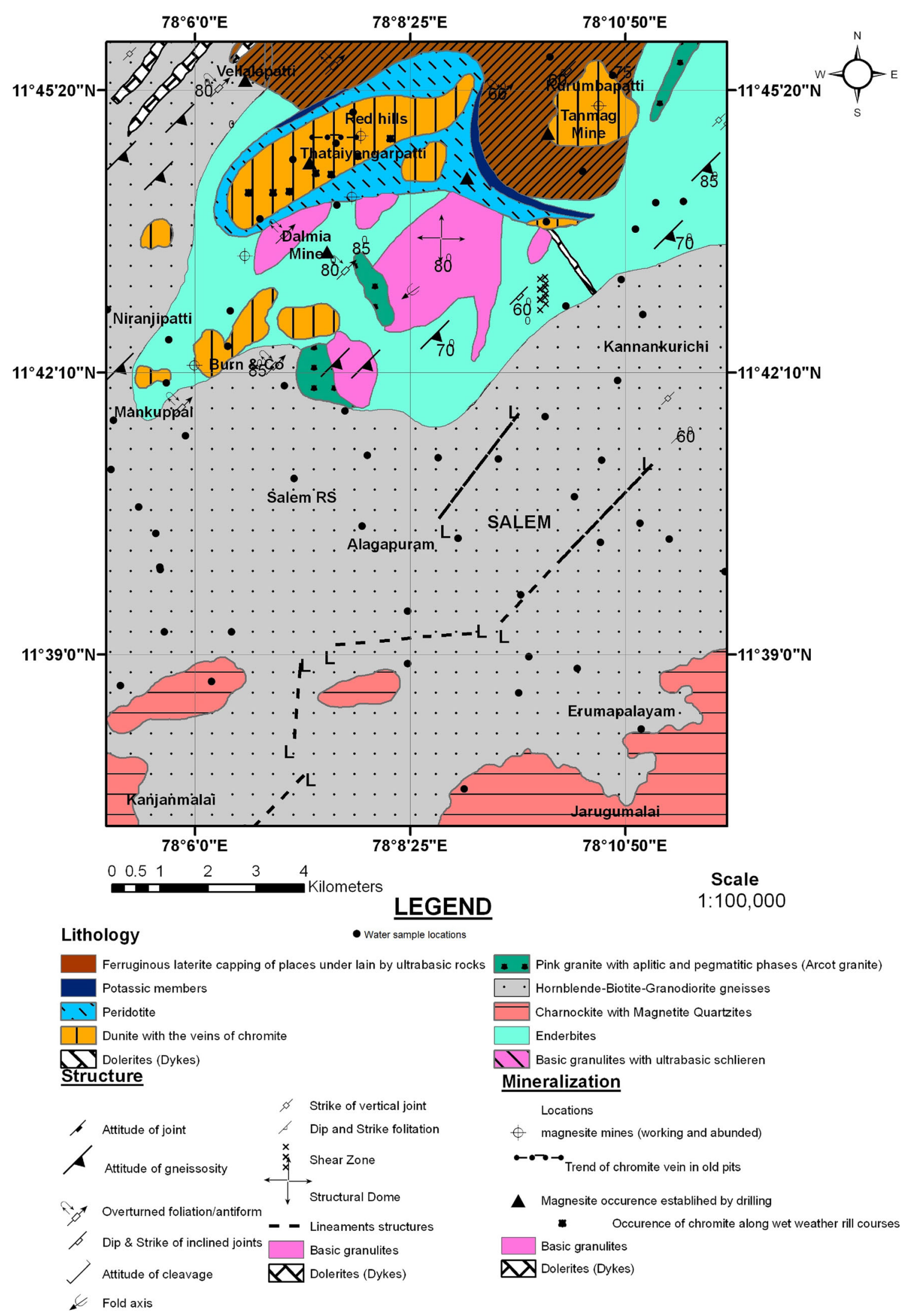

Fig. 1 Geological map of the study area in Salem, southern India (Modified after Periakali 1982) 
granulites, hornblende-biotite granodiorite, gneisses and amphibolite, pink granite, pegmatites, dolerites, ultramafic and alkaline rocks. The ultramafic and alkaline rocks are composed of dunites, peridotites, shonkinites and syenites and are important as they are major contributors to the trace element budget of soil and water. They occur as intrusives amidst the highly metamorphosed rocks (amphibolites and granulites) that have been subjected to successive periods of deformation. The weathering of ultramafic rocks has resulted in not only the enrichment of trace elements particularly $\mathrm{Ni}, \mathrm{Cr}$ and $\mathrm{Co}$ in soil, and subsequently in groundwater, but also deterioration of water quality (Periakali et al. 1999). The analytical data obtained from rock, soil and water samples were used to derive inter-element associations and to understand factors contributing to groundwater quality. In the present study, factor analysis has been carried out to show the interrelationship existing between a number of variables with the help of few factors.

\section{Factor analysis}

The R-mode is chosen as it has several positive features in interpreting geochemical data (Lawrence and Upchurch 1982). The raw data were standardized to have a mean of zero and standard deviation of one. Correlation coefficient $r$ is given by the equation.

$r=(d x . d y) /\left(n \sum x . \sum y\right)$

where $d x, d y$ are the mean derivatives of values in $x$ and $y$ series, $\mathrm{n}$ is the number of items and $\sum x, \sum y$ are the standard deviations of $x$ and $y$ (Davis 2002). Correlation coefficients of the variables are computed from the standardized variables. The correlation coefficient matrix quantifies the linear relationship existing between pairs of variables present therein. The percentages of eigenvalues are computed since the eigenvalues quantify the contribution of a factor to the total variation. The contribution of a factor is said to be significant when the corresponding eigenvalue is greater than unity. The factor 1 will be related to the largest eigenvalue and will explain the greatest amount of variance in the data set. The factor 2 explains the greatest of the remaining variance and so forth. Regionally distributed, lithologically controlled variables are generally extracted first and then the more local pathway/origin controlled variables are identified (Lawrence and Upchurch 1982). A step has been taken to rotate the factors (varimax rotated) in such a way that all their components are closer to $+1,0$ or -1 , representing the importance of each variable (Briz-Kishore and Murali 1992; Davis 2002). Thus, where factor loadings are high, it can be assumed that the variable contributes to that factor (Lawrence and Upchurch 1982). If the factor loadings have a negative sign, it indicates a negative correlation with the factor.

\section{Methodology}

Thirty-four soil samples were collected and analysed for major oxides $\left(\mathrm{SiO}_{2}, \mathrm{Al}_{2} \mathrm{O}_{3}, \mathrm{TiO}_{2}, \mathrm{Fe}_{2} \mathrm{O}_{3}, \mathrm{MnO}, \mathrm{MgO}, \mathrm{CaO}\right.$, $\mathrm{Na}_{2} \mathrm{O}$ and $\mathrm{K}_{2} \mathrm{O}$ ), and minor and trace elements ( $\mathrm{Fe}, \mathrm{Mn}, \mathrm{Ni}$, $\mathrm{Cr}$ and $\mathrm{Co}$ ) following standard procedures (Jackson 1967). The analytical error in terms of the \%RSD for major oxides varied from 2 to $3 \%$, while for the minor and trace elements, it is between 2 and $6 \%$. Major ion chemistry, $\mathrm{SiO}_{2}$, $\mathrm{pH}, \mathrm{EC}$, total dissolved solids (TDS), $\mathrm{Ca}, \mathrm{Mg}, \mathrm{Na}, \mathrm{K}, \mathrm{Cl}$, $\mathrm{SO}_{4}, \mathrm{CO}_{3}, \mathrm{HCO}_{3}$ and $\mathrm{NO}_{3}$, and minor and trace elements (Fe, $\mathrm{Mn}, \mathrm{Ni}, \mathrm{Cr}$ and $\mathrm{Co}$ ) were determined from 55 groundwater samples taken for six different periods [summer (May) and winter (November) seasons from 1997 to 1999] following standard procedures (APHA 1995). The analytical data thus acquired were within the permissible analytical errors (better than $3 \%$ RSD). Trivalent and hexavalent chromium were determined using chemical separation and analysis by Atomic Absorption Spectrometry (Varian ${ }^{\circledR}$ SpectrAA 200) for the samples collected during summer and winter seasons of 1997 and 1998. The data for 1999 were not acquired due to constraints in analytical work. The standard error for chromium speciation data varied from 2 to $3 \%$. All chemical analysis was carried out at the University of Madras (Guindy campus), Chennai, India. The soil and water analytical data are presented in Satyanarayanan and Periakali (2002, 2003 2004). The analytical data of fifteen ultramafic rock samples of Periakali (1982) for the study area were utilized to compare and contrast the inferences obtained from the analysis of soil and water. Only those parameters that were determined for soil and water were statistically analysed to understand the nature of association of various components. The geochemical data were further subjected to R-mode factor analysis using SPSS (Statistical Package for Social Sciences 1995) software (version 7.5) and the statistically significant factors extracted.

\section{Results and discussion}

\section{Rock}

The factor analysis data (Table 1) were used to infer the factors responsible for the distribution of trace elements ( $\mathrm{Ni}, \mathrm{Cr}$ and $\mathrm{Co}$ ) in ultramafic rocks. The data show that three factors account for $93.8 \%$ of the variance in the data. Factor 1, which describes $71.5 \%$ of the variance, has 
Table 1 Factor analytical results of rock samples from the study area

\begin{tabular}{llllrrrrr}
\hline Variable & Communality & Factor & Eigen value & \% of Var & Cum \% & Factor 1 & Factor 2 & Factor 3 \\
\hline$\% \mathrm{Al}$ & 1.00 & 1 & 8.59 & 71.50 & 71.50 & $\mathbf{- 0 . 9 5}$ & -0.29 & -0.09 \\
$\% \mathrm{Ca}$ & 0.90 & 2 & 1.63 & 13.60 & 85.10 & 0.35 & $\mathbf{0 . 7 1}$ & $\mathbf{0 . 5 3}$ \\
$\mathrm{Co}$ & 0.98 & 3 & 1.04 & 8.70 & 93.80 & $\mathbf{0 . 9 6}$ & -0.14 & 0.19 \\
$\mathrm{Cr}$ & 0.99 & 4 & 0.63 & 5.20 & 99.00 & $\mathbf{0 . 8 9}$ & 0.43 & -0.07 \\
$\% \mathrm{Fe}$ & 0.84 & 5 & 0.11 & 0.90 & 99.90 & 0.29 & 0.43 & $\mathbf{0 . 7 5}$ \\
$\% \mathrm{~K}$ & 1.00 & 6 & 0.01 & 0.10 & 100.00 & $\mathbf{- 0 . 9 4}$ & -0.34 & -0.06 \\
$\% \mathrm{Mg}$ & 0.99 & 7 & & & & $\mathbf{0 . 9 7}$ & 0.22 & -0.03 \\
$\% \mathrm{Mn}$ & 0.88 & 8 & & & & 0.27 & $\mathbf{0 . 9 0}$ & -0.06 \\
$\% \mathrm{Na}$ & 0.99 & 9 & & & & $\mathbf{- 0 . 9 4}$ & -0.33 & -0.06 \\
$\mathrm{Ni}$ & 0.99 & 10 & & & & $\mathbf{0 . 9 4}$ & 0.32 & 0.08 \\
$\% \mathrm{Si}$ & 0.99 & 11 & & & & -0.85 & -0.43 & -0.28 \\
$\% \mathrm{Ti}$ & 0.70 & 12 & & & & -0.10 & -0.13 \\
\hline
\end{tabular}

Significant factor loadings with more than 0.50 are given in bold

positive loading on nickel, chromium, cobalt and magnesium, and negative loading on silica, aluminium, sodium and potassium. This indicates that the trace metals nickel, chromium and cobalt are enriched and associated with each other in the ultramafic rocks, as observed by many workers in the study area (Windley and Selvan 1975; Viswanathan and Nagendra Kumar 1982; Periakali 1982; Kutty et al. 1986; Reddy et al. 1995; Subramanian and Selvan 2001). Silica, aluminium, sodium and potassium show a negative trend in ultramafic rocks. Factor 2, which describes $13.6 \%$ of the variance, has positive loading on calcium and manganese. Factor 3 describes $8.7 \%$ of the variance, with positive loading on total iron, titanium and calcium and it explains their contribution from the accessory mineral titanomagnetite of ultrabasic rocks of the study area (Kalaiselvan 1994).

\section{Soil}

Factor analytical results (Table 2) were used to determine the factors responsible for the distribution of trace elements in soil. The results show that six factors account for $84 \%$ of the variance in the data. Factor 1, which describes $25.6 \%$ of the variance, has high positive loading on $\mathrm{CaO}$ and $\mathrm{MgO}$, and negative loading on $\mathrm{Al}_{2} \mathrm{O}_{3}$ and $\mathrm{SiO}_{2}$. This shows that the type of soil in the study area is calcimagnesian rather than aluminosilicate. Factor 2, which describes $21.9 \%$ of the variance, has positive loading on nickel, chromium and cobalt indicating their association with each other and derivation from a common source. Factor 3, which describes $12.5 \%$ of the variance, has positive loading on $\mathrm{pH}, \mathrm{TiO}_{2}$ and $\mathrm{K}_{2} \mathrm{O}$ and negative loading on $\mathrm{CaCO}_{3}$, implying that at high $\mathrm{pH}$, the oxides of titanium and potassium are mobile when compared to calcium carbonate in soils. Factor 4, which describes
$11.3 \%$ of the variance, has positive loading on silt and negative loading on sand. This factor explains that the sand percentage in soil decreases with increase in silt content. Factor 5, which describes $6.6 \%$ of the variance, has positive loading on $\mathrm{Fe}_{2} \mathrm{O}_{3}$ and $\mathrm{MnO}$, which shows that manganese is related to iron in its chemical properties and is a member of the iron family (Raymahashay 1996) or the ferrides (Krauskopf 1979). Factor 6, which describes $5.9 \%$ of the variance, has positive loading on clay percentage and organic carbon. The association of clay with organic carbon clearly confirms the affinity of humic substances to clay-sized particles.

\section{Groundwater quality in summer}

The factor analytical results show that five factors account for $71.2 \%$ variance in the data (Table 3). Factor 1 is loaded with Ec, TDS, $\mathrm{Mg}, \mathrm{Cl}, \mathrm{Na}$ and $\mathrm{SO}_{4}$, and it accounts for $30.4 \%$ of the variance. This shows that the TDS are influenced by the major ions of $\mathrm{Mg}, \mathrm{Na}, \mathrm{Cl}$ and $\mathrm{SO}_{4}$. This factor can be explained for large residence time of groundwater/low hydraulic conductivity, greater rock-water interaction and greater solubility of minerals (Scanlon, 1989; Henry and Shwartz 1990). Salem district is underlain entirely by Archaean rocks comprising granite gneiss, charnockite, granites and other associated consolidated crystalline rocks devoid of primary porosity but rendered porous and permeable with the development of secondary fracturing, inducing relatively longer residence time of groundwater. The pumping rate in bore wells varies from 20 to $500 \mathrm{lpm}$ and depends on the depth of the bore well (Subburaj, 2008). High loading on $\mathrm{SO}_{4}$ indicates pollution from application of fertilizers to agricultural lands or industrial pollution (Berner and Berner 1987; Scanlon 1989; Cain et al. 1989). Simple irrigation system in which 
Table 2 Factor analytical results of soils collected from the study area

\begin{tabular}{|c|c|c|c|c|c|c|c|c|c|c|c|}
\hline Variable & Communality & Factor & Eigen value & $\%$ of Var & Cum $\%$ & Factor 1 & Factor 2 & Factor 3 & Factor 4 & Factor 5 & Factor 6 \\
\hline $\mathrm{Al}_{2} \mathrm{O}_{3}$ & 0.75 & 1 & 4.87 & 25.60 & 25.60 & -0.73 & -0.25 & 0.34 & 0.09 & -0.11 & -0.14 \\
\hline $\mathrm{CaCO}_{3}$ & 0.79 & 2 & 4.17 & 21.90 & 47.60 & 0.15 & -0.03 & -0.84 & 0.17 & 0.15 & 0.09 \\
\hline $\mathrm{CaO}$ & 0.97 & 3 & 2.38 & 12.50 & 60.10 & 0.95 & -0.08 & -0.15 & -0.07 & -0.18 & 0.08 \\
\hline CEC & 0.48 & 4 & 2.15 & 11.30 & 71.50 & 0.36 & -0.05 & 0.05 & 0.30 & -0.13 & 0.48 \\
\hline Clay (\%) & 0.73 & 5 & 1.26 & 6.60 & 78.10 & -0.08 & -0.23 & 0.05 & -0.32 & 0.03 & 0.75 \\
\hline Co & 0.96 & 6 & 1.12 & 5.90 & 84.00 & -0.05 & 0.96 & -0.05 & 0.05 & 0.20 & -0.01 \\
\hline $\mathrm{Cr}$ & 0.95 & 7 & 0.78 & 4.10 & 88.10 & -0.07 & 0.95 & -0.09 & 0.05 & 0.15 & -0.07 \\
\hline $\mathrm{Fe}_{2} \mathrm{O}_{3}$ & 0.95 & 8 & 0.67 & 3.50 & 91.60 & -0.18 & 0.15 & -0.04 & -0.08 & 0.94 & -0.06 \\
\hline $\mathrm{K}_{2} \mathrm{O}$ & 0.71 & 9 & 0.52 & 2.70 & 94.30 & -0.01 & -0.23 & 0.78 & 0.22 & 0.06 & -0.04 \\
\hline $\mathrm{MgO}$ & 0.97 & 10 & 0.38 & 2.00 & 96.30 & 0.95 & -0.08 & -0.15 & -0.07 & -0.18 & 0.08 \\
\hline $\mathrm{MnO}$ & 0.94 & 11 & 0.35 & 1.80 & 98.10 & -0.08 & 0.45 & -0.02 & -0.11 & 0.85 & -0.08 \\
\hline $\mathrm{Na}_{2} \mathrm{O}$ & 0.88 & 12 & 0.15 & 0.80 & 98.90 & -0.15 & -0.49 & 0.76 & -0.09 & -0.17 & -0.08 \\
\hline $\mathrm{Ni}$ & 0.93 & 13 & 0.11 & 0.60 & 99.50 & -0.12 & 0.84 & -0.40 & 0.10 & 0.16 & 0.05 \\
\hline $\mathrm{OC}$ & 0.59 & 14 & 0.06 & 0.30 & 99.80 & 0.19 & 0.18 & -0.21 & 0.01 & -0.07 & 0.68 \\
\hline $\mathrm{pH}$ & 0.74 & 15 & & & & 0.43 & 0.38 & 0.62 & -0.06 & -0.06 & -0.17 \\
\hline Sand (\%) & 0.94 & 16 & & & & 0.13 & -0.06 & 0.00 & -0.96 & 0.07 & 0.01 \\
\hline Silt & 0.97 & 17 & & & & -0.11 & 0.09 & -0.01 & 0.96 & -0.07 & -0.11 \\
\hline $\mathrm{SiO}_{2}$ & 0.96 & 18 & & & & -0.88 & 0.29 & -0.29 & 0.09 & 0.05 & -0.07 \\
\hline $\mathrm{TiO}_{2}$ & 0.74 & 19 & & & & -0.22 & -0.28 & 0.69 & 0.05 & 0.33 & 0.15 \\
\hline
\end{tabular}

Significant factor loadings with more than 0.50 are given in bold

Table 3 Factor analytical results of groundwater samples collected during summer in the study area

\begin{tabular}{|c|c|c|c|c|c|c|c|c|c|c|}
\hline Parameter & Communality & Factor & Eigen value & $\%$ of Var & Cum $\%$ & Factor 1 & Factor 2 & Factor 3 & Factor 4 & Factor 5 \\
\hline $\mathrm{Ca}$ & 0.56 & 1 & 5.77 & 30.40 & 30.40 & 0.24 & 0.07 & 0.32 & -0.51 & 0.36 \\
\hline $\mathrm{Cl}$ & 0.83 & 2 & 2.67 & 14.10 & 44.40 & 0.82 & 0.08 & -0.29 & 0.12 & 0.24 \\
\hline Co & 0.49 & 3 & 2.11 & 11.10 & 55.50 & 0.38 & -0.24 & -0.52 & -0.15 & 0.02 \\
\hline $\mathrm{CO}_{3}$ & 0.66 & 4 & 1.69 & 8.90 & 64.40 & 0.00 & -0.15 & 0.79 & -0.07 & 0.08 \\
\hline $\mathrm{Cr}$ & 0.58 & 5 & 1.47 & 7.80 & 72.20 & -0.04 & -0.11 & 0.26 & -0.16 & -0.69 \\
\hline Depth & 0.63 & 6 & 0.91 & 4.80 & 77.00 & 0.07 & -0.03 & 0.01 & 0.03 & 0.79 \\
\hline $\mathrm{Ec}$ & 0.99 & 7 & 0.83 & 4.40 & 81.30 & 0.94 & 0.28 & 0.01 & 0.05 & 0.14 \\
\hline $\mathrm{Fe}$ & 0.67 & 8 & 0.72 & 3.80 & 85.10 & 0.05 & 0.02 & -0.09 & 0.69 & 0.42 \\
\hline $\mathrm{HCO}_{3}$ & 0.69 & 9 & 0.61 & 3.20 & 88.30 & 0.19 & 0.60 & 0.39 & -0.24 & 0.29 \\
\hline K & 0.92 & 10 & 0.57 & 3.00 & 91.30 & 0.08 & 0.95 & -0.04 & 0.04 & -0.03 \\
\hline $\mathrm{Mg}$ & 0.73 & 11 & 0.51 & 2.70 & 94.00 & 0.75 & -0.07 & 0.33 & 0.22 & -0.05 \\
\hline $\mathrm{Mn}$ & 0.75 & 12 & 0.37 & 1.90 & 95.90 & 0.27 & 0.06 & 0.00 & 0.82 & 0.09 \\
\hline $\mathrm{Na}$ & 0.82 & 13 & 0.34 & 1.80 & 97.70 & 0.78 & 0.34 & -0.28 & 0.05 & 0.14 \\
\hline $\mathrm{Ni}$ & 0.49 & 14 & 0.23 & 1.20 & 98.90 & 0.37 & 0.00 & 0.27 & 0.53 & -0.03 \\
\hline $\mathrm{NO}_{3}$ & 0.93 & 15 & 0.19 & 1.00 & 99.90 & 0.16 & 0.95 & -0.04 & 0.08 & 0.01 \\
\hline $\mathrm{pH}$ & 0.73 & 16 & & & & -0.39 & 0.05 & 0.67 & -0.30 & -0.17 \\
\hline $\mathrm{Si}$ & 0.44 & 17 & & & & -0.04 & -0.06 & -0.60 & -0.10 & 0.25 \\
\hline $\mathrm{SO}_{4}$ & 0.82 & 18 & & & & 0.84 & -0.17 & -0.16 & 0.16 & -0.20 \\
\hline TDS & 0.99 & 19 & & & & 0.94 & 0.28 & 0.00 & 0.05 & 0.13 \\
\hline
\end{tabular}

Significant factor loadings with more than 0.50 are given in bold

water from dug wells is used for growing crops in the study area. Fertilizers such as urea, diammonium phosphate (DAP), potash are used during farming in these regions. A number of industrial units including textile units, sugar mills and sago factories exist in Salem district, the effluents from which have caused local pollution of surface and 
ground water resources. Excessive use of fertilizers and pesticides in agriculture has also reportedly resulted in localized enrichment of sulphates and nitrates in the phreatic zone (Subburaj 2008). Factor 2 is loaded with K, $\mathrm{HCO}_{3}$ and $\mathrm{NO}_{3}$ and accounts for $14.1 \%$ of the variance. This factor indicates the supply of $\mathrm{K}$ and $\mathrm{NO}_{3}$ to the soil through the application of fertilizers and infiltration into the groundwater (Ballukraya and Ravi 1999). Factor 3, which describes $11.1 \%$ of the common variance, has positive loading for $\mathrm{pH}$ and $\mathrm{CO}_{3}$ which indicates that the alkalinity of groundwater is associated with post-rainfall periods, when an increase in $\mathrm{pH}$ of the groundwater is noticed. When the carbonate hydrolyses, it produces the bicarbonate ion and hydroxide ion. The hydroxide ion makes the solution basic. $\left[\mathrm{CO}_{3}{ }^{2-}+\mathrm{H}_{2} \mathrm{O}<==>\mathrm{HCO}_{3}{ }^{-}+\mathrm{OH}^{-}\right]$. Increase in $\mathrm{pH}$ leads to conversion of $\mathrm{HCO}_{3}$ to $\mathrm{CO}_{2}$ (Berner and Berner 1987). A detailed account of the water type using Piper diagram is given elsewhere (Satyanarayanan and Periakali 2002). Further, it was observed that the concentrations of Co and silica, determined by geogenic influences, have negative loading and decrease with increase in alkalinity. Factor 4, which describes $8.9 \%$ of the common variance, has positive loading for $\mathrm{Fe}, \mathrm{Mn}$ and $\mathrm{Ni}$, and negative loading for calcium. This shows that the influence of $\mathrm{Fe}$ - and $\mathrm{Mn}$-bearing minerals rather than $\mathrm{Ca}$ is predominant in increasing the concentration of $\mathrm{Ni}$ during summer. Factor 5 has positive loading for depth and negative loading for $\mathrm{Cr}$, accounting for $7.8 \%$ of the variance. This clearly explains that in the upper layer, the influence of $\mathrm{Cr}$ predominates than in the deeper layers. These investigations, when correlated with field observations, reveal that the increased concentration of $\mathrm{Cr}$ in groundwater is due to magnesite mineralization in ultrabasic rocks.

\section{Groundwater quality in winter}

During winter, the factor analytical results show that six factors account for $73.7 \%$ of the variance of the data (Table 4). Factor 1 is loaded with Ec, TDS, $\mathrm{Mg}, \mathrm{Na}, \mathrm{Cl}$ and $\mathrm{SO}_{4}$, and it accounts for $30.9 \%$ of the variance. Similar observations during summer reveal that the TDS is influenced mainly by the major ions of $\mathrm{Mg}, \mathrm{Na}, \mathrm{Cl}$ and $\mathrm{SO}_{4}$, and the groundwater chemistry is controlled by these four ions in the study area. Factor 2, which describes $11.3 \%$ of the variance, has high positive loading for $\mathrm{K}_{\text {and }} \mathrm{NO}_{3}$, influenced by rainfall on the application of fertilizers to the soil and their infiltration into the groundwater system. $\mathrm{K}$ and $\mathrm{NO}_{3}$ are major pollutants (Berner and Berner 1987; Melloul and Collin 1992). High positive loading of K can be attributed to the application of fertilizers in the agricultural areas as is also evident from inferences drawn on groundwater quality in summer. Similarly, high positive loading of nitrate is from domestic sewage effluents. The oxic environment prevailing in sand aquifers promotes nitrate formation from sewage sources (Scanlon 1990; Peddorson et al. 1991). Factor 3, which describes $9.8 \%$ of the variance, is positively loaded with $\mathrm{HCO}_{3}$ and negative with silica. High loading on $\mathrm{HCO}_{3}$ can be attributed to the $\mathrm{CO}_{2}$ present in the soil. Oxidation of organic matter by microbes generates $\mathrm{CO}_{2}$, which then combines with water to form carbonic acid (Raymahashay 1996) and dissociates to $\mathrm{H}$ and $\mathrm{HCO}_{3}$ ions.

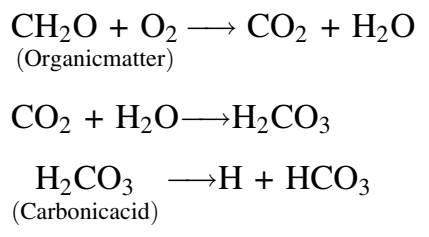

Factor 4, which describes $8.6 \%$ of the variance, has positive loading on depth of the well and $\mathrm{Fe}$, and negative loading on $\mathrm{Cr}$. The association of depth with $\mathrm{Cr}$ was also observed during summer season. This indicates, undoubtedly, that the persistence of $\mathrm{Cr}$ in groundwater is shallow in nature and influenced by mining activity during the recent past. The association of $\mathrm{Fe}$ with these components during winter explains that the rainfall and rock-water mechanism act as a predominant factor in influencing the concentration of $\mathrm{Cr}$ in groundwater. Factor 5, which describes $7.3 \%$ of the variance, has positive loading for $\mathrm{Mn}$ and $\mathrm{CO}_{3}$, and negative loading for $\mathrm{Ni}$. This indicates that $\mathrm{Ni}$ concentration is low in $\mathrm{Mn}$ - and $\mathrm{CO}_{3^{-}}$ enriched environment. Factor 6, which describes $5.9 \%$ of the variance, is positively loaded with Co and negatively loaded with $\mathrm{Ca}$, confirming that Co concentration is low in Ca-rich groundwater of the study area.

\section{Trivalent and hexavalent chromium in groundwater}

Factor analysis was applied to a matrix of 110 samples (55 in each season) and 21 water components collected and analysed during 1997 and 1998 to find out the main influences on seasonal changes in the trivalent and hexavalent chromium loading in groundwater. The results of the factor analysis from data obtained during summer and winter are given in Tables 5 and 6, respectively. The factor analytical results during summer show that six factors account for $75.8 \%$ of the variance in the data (Table 5). Trivalent and total $\mathrm{Cr}$ are negatively loaded on factor 3 , which describes $11.6 \%$ of the variance. Depth of the well is loaded positively, as observed earlier for total chromium. This indicates that during summer, total $\mathrm{Cr}$ is in the form of $\mathrm{Cr}$ (III), and with depth, the concentrations of both decrease. The hexavalent form of $\mathrm{Cr}$ is located positively on factor 5 , which describes $7.5 \%$ of the variance. Ni is negatively loaded on this factor, which shows that an 
Table 4 Factor analytical results of groundwater samples collected during winter in the study area

\begin{tabular}{|c|c|c|c|c|c|c|c|c|c|c|c|}
\hline Parameter & Communality & Factor & Eigen value & $\%$ of Var & Cum $\%$ & Factor 1 & Factor 2 & Factor 3 & Factor 4 & Factor 5 & Factor 6 \\
\hline $\mathrm{Ca}$ & 0.75 & 1 & 5.87 & 30.90 & 30.90 & 0.19 & 0.05 & -0.06 & 0.06 & 0.15 & 0.83 \\
\hline $\mathrm{Cl}$ & 0.88 & 2 & 2.14 & 11.30 & 42.10 & 0.85 & 0.18 & -0.02 & 0.06 & 0.11 & 0.34 \\
\hline Co & 0.74 & 3 & 1.85 & 9.80 & 51.90 & 0.58 & 0.07 & -0.24 & 0.17 & 0.00 & -0.55 \\
\hline $\mathrm{CO}_{3}$ & 0.71 & 4 & 1.63 & 8.60 & 60.50 & 0.05 & -0.01 & 0.48 & -0.04 & -0.69 & -0.01 \\
\hline $\mathrm{Cr}$ & 0.64 & 5 & 1.40 & 7.30 & 67.80 & -0.03 & -0.07 & -0.02 & -0.75 & 0.21 & -0.12 \\
\hline Depth & 0.46 & 6 & 1.12 & 5.90 & 73.70 & 0.07 & -0.10 & 0.14 & 0.64 & 0.05 & 0.08 \\
\hline Ec & 0.98 & 7 & 0.87 & 4.60 & 78.30 & 0.93 & 0.23 & 0.13 & 0.06 & 0.11 & 0.16 \\
\hline $\mathrm{Fe}$ & 0.53 & 8 & 0.80 & 4.20 & 82.50 & -0.06 & 0.07 & -0.01 & 0.66 & 0.22 & -0.18 \\
\hline $\mathrm{HCO}_{3}$ & 0.69 & 9 & 0.73 & 3.80 & 86.30 & 0.16 & 0.12 & 0.80 & 0.08 & 0.05 & -0.03 \\
\hline K & 0.98 & 10 & 0.57 & 3.00 & 89.30 & 0.20 & 0.96 & 0.10 & 0.01 & 0.08 & 0.00 \\
\hline $\mathrm{Mg}$ & 0.79 & 11 & 0.53 & 2.80 & 92.20 & 0.73 & 0.01 & 0.10 & -0.06 & -0.20 & 0.44 \\
\hline $\mathrm{Mn}$ & 0.51 & 12 & 0.38 & 2.00 & 94.10 & 0.19 & 0.09 & 0.19 & 0.04 & 0.65 & -0.02 \\
\hline $\mathrm{Na}$ & 0.86 & 13 & 0.34 & 1.80 & 95.90 & 0.81 & 0.26 & 0.13 & 0.11 & 0.24 & -0.22 \\
\hline $\mathrm{Ni}$ & 0.68 & 14 & 0.28 & 1.50 & 97.40 & 0.28 & -0.06 & 0.08 & 0.04 & 0.65 & 0.41 \\
\hline $\mathrm{NO}_{3}$ & 0.98 & 15 & 0.25 & 1.30 & 98.80 & 0.28 & 0.94 & 0.10 & 0.03 & -0.01 & 0.03 \\
\hline $\mathrm{pH}$ & 0.60 & 16 & 0.22 & 1.20 & 99.90 & -0.41 & -0.14 & 0.25 & -0.46 & -0.28 & 0.24 \\
\hline $\mathrm{Si}$ & 0.69 & 17 & & & & 0.09 & -0.06 & -0.82 & -0.05 & -0.01 & -0.06 \\
\hline $\mathrm{SO}_{4}$ & 0.75 & 18 & & & & 0.81 & 0.07 & -0.19 & 0.01 & 0.16 & -0.16 \\
\hline TDS & 0.79 & 19 & & & & 0.86 & 0.11 & 0.13 & -0.01 & 0.13 & 0.11 \\
\hline
\end{tabular}

Significant factor loadings with more than 0.50 are given in bold

Table 5 Factor analytical results of groundwater samples collected during summer 1997 and 1998 in the study area

\begin{tabular}{|c|c|c|c|c|c|c|c|c|c|c|c|}
\hline Parameter & Communality & Factor & Eigen Value & $\%$ of Var & Cum $\%$ & Factor 1 & Factor 2 & Factor 3 & Factor 4 & Factor 5 & Factor 6 \\
\hline $\mathrm{Ca}$ & 0.53 & 1 & 5.71 & 27.20 & 27.20 & 0.25 & 0.02 & 0.21 & 0.35 & 0.01 & -0.55 \\
\hline $\mathrm{Cl}$ & 0.82 & 2 & 2.91 & 13.90 & 41.00 & 0.83 & 0.06 & 0.26 & -0.19 & 0.08 & 0.13 \\
\hline Co & 0.53 & 3 & 2.44 & 11.60 & 52.70 & 0.41 & -0.27 & -0.02 & -0.28 & 0.46 & 0.00 \\
\hline $\mathrm{CO}_{3}$ & 0.70 & 4 & 2.18 & 10.40 & 63.00 & -0.05 & -0.12 & 0.00 & 0.82 & -0.07 & -0.05 \\
\hline $\mathrm{Cr}$ & 0.87 & 5 & 1.58 & 7.50 & 70.60 & -0.05 & -0.08 & -0.90 & 0.20 & 0.04 & -0.09 \\
\hline $\mathrm{Cr}(\mathrm{III})$ & 0.86 & 6 & 1.08 & 5.20 & 75.80 & -0.02 & -0.13 & -0.89 & 0.21 & 0.05 & -0.11 \\
\hline Cr(IV) & 0.78 & 7 & 0.98 & 4.70 & 80.40 & 0.04 & 0.10 & 0.01 & -0.17 & 0.86 & 0.06 \\
\hline Depth & 0.46 & 8 & 0.80 & 3.80 & 84.20 & 0.11 & -0.04 & 0.65 & 0.12 & 0.06 & 0.01 \\
\hline $\mathrm{Ec}$ & 0.99 & 9 & 0.70 & 3.30 & 87.50 & 0.95 & 0.28 & 0.11 & 0.08 & -0.05 & -0.02 \\
\hline $\mathrm{Fe}$ & 0.76 & 10 & 0.62 & 3.00 & 90.50 & 0.12 & 0.00 & 0.32 & 0.11 & 0.10 & 0.79 \\
\hline $\mathrm{HCO}_{3}$ & 0.66 & 11 & 0.54 & 2.60 & 93.10 & 0.19 & 0.58 & 0.15 & 0.42 & -0.03 & -0.29 \\
\hline K & 0.90 & 12 & 0.42 & 2.00 & 95.10 & 0.08 & 0.94 & 0.01 & -0.06 & 0.00 & 0.04 \\
\hline $\mathrm{Mg}$ & 0.71 & 13 & 0.36 & 1.70 & 96.80 & 0.71 & -0.07 & -0.04 & 0.32 & -0.28 & 0.14 \\
\hline $\mathrm{Mn}$ & 0.78 & 14 & 0.26 & 1.20 & 98.00 & 0.28 & 0.05 & 0.09 & 0.06 & -0.32 & 0.77 \\
\hline $\mathrm{Na}$ & 0.80 & 15 & 0.22 & 1.00 & 99.10 & 0.77 & 0.36 & 0.13 & -0.22 & 0.13 & 0.01 \\
\hline $\mathrm{Ni}$ & 0.79 & 16 & 0.17 & 0.80 & 99.80 & 0.32 & 0.03 & 0.00 & 0.04 & -0.80 & 0.22 \\
\hline $\mathrm{NO}_{3}$ & 0.93 & 17 & 0.02 & 0.10 & 99.90 & 0.16 & 0.94 & 0.05 & -0.05 & 0.02 & 0.08 \\
\hline $\mathrm{pH}$ & 0.73 & 18 & & & & -0.45 & 0.08 & -0.22 & 0.59 & -0.15 & -0.31 \\
\hline $\mathrm{Si}$ & 0.50 & 19 & & & & 0.01 & -0.09 & 0.20 & -0.63 & 0.17 & -0.16 \\
\hline $\mathrm{SO}_{4}$ & 0.80 & 20 & & & & 0.85 & -0.16 & -0.15 & -0.15 & -0.13 & 0.05 \\
\hline TDS & 0.99 & 21 & & & & 0.95 & 0.27 & 0.11 & 0.07 & -0.04 & -0.01 \\
\hline
\end{tabular}

Significant factor loadings with more than 0.50 are given in bold 
Table 6 Factor analytical results of Groundwater samples collected during winter 1997 and 1998 in the study area

\begin{tabular}{|c|c|c|c|c|c|c|c|c|c|c|c|}
\hline Parameter & Communality & Factor & Eigen value & $\%$ of Var & Cum \% & Factor 1 & Factor 2 & Factor 3 & Factor 4 & Factor 5 & Factor 6 \\
\hline $\mathrm{Ca}$ & 0.66 & 1 & 6.17 & 29.40 & 29.4 & 0.25 & -0.03 & 0.00 & 0.11 & 0.24 & -0.73 \\
\hline $\mathrm{Cl}$ & 0.88 & 2 & 2.99 & 14.20 & 43.6 & 0.90 & -0.10 & -0.05 & 0.20 & 0.10 & -0.02 \\
\hline Co & 0.79 & 3 & 2.30 & 11.00 & 54.6 & 0.54 & -0.26 & -0.36 & -0.04 & -0.32 & 0.44 \\
\hline $\mathrm{CO}_{3}$ & 0.80 & 4 & 1.71 & 8.20 & 62.7 & 0.05 & 0.03 & 0.61 & -0.10 & -0.64 & 0.02 \\
\hline $\mathrm{Cr}$ & 0.81 & 5 & 1.42 & 6.80 & 69.5 & -0.06 & 0.86 & -0.06 & -0.05 & 0.12 & 0.22 \\
\hline $\mathrm{Cr}(\mathrm{III})$ & 0.79 & 6 & 1.15 & 5.50 & 75 & -0.09 & 0.69 & 0.14 & -0.05 & 0.53 & -0.11 \\
\hline $\mathrm{Cr}(\mathrm{IV})$ & 0.82 & 7 & 0.96 & 4.60 & 79.5 & 0.18 & 0.88 & -0.01 & -0.09 & 0.03 & 0.02 \\
\hline Depth & 0.30 & 8 & 0.81 & 3.90 & 83.4 & 0.11 & -0.47 & 0.16 & -0.11 & 0.17 & 0.02 \\
\hline Ec & 0.98 & 9 & 0.69 & 3.30 & 86.7 & 0.95 & -0.08 & 0.10 & 0.21 & 0.11 & -0.04 \\
\hline $\mathrm{Fe}$ & 0.41 & 10 & 0.65 & 3.10 & 89.7 & -0.01 & -0.52 & -0.03 & 0.11 & 0.11 & 0.34 \\
\hline $\mathrm{HCO}_{3}$ & 0.74 & 11 & 0.38 & 1.80 & 91.6 & 0.09 & -0.09 & 0.83 & 0.11 & 0.15 & -0.06 \\
\hline K & 0.98 & 12 & 0.36 & 1.70 & 93.3 & 0.22 & -0.05 & 0.09 & 0.96 & 0.07 & -0.01 \\
\hline $\mathrm{Mg}$ & 0.77 & 13 & 0.34 & 1.60 & 94.9 & 0.84 & 0.10 & 0.08 & 0.06 & -0.16 & -0.14 \\
\hline $\mathrm{Mn}$ & 0.56 & 14 & 0.28 & 1.30 & 96.2 & 0.28 & -0.05 & 0.08 & 0.19 & 0.42 & 0.51 \\
\hline $\mathrm{Na}$ & 0.84 & 15 & 0.27 & 1.30 & 97.5 & 0.85 & -0.15 & 0.09 & 0.20 & 0.19 & 0.11 \\
\hline $\mathrm{Ni}$ & 0.78 & 16 & 0.21 & 1.00 & 98.5 & 0.29 & -0.02 & 0.08 & -0.02 & 0.82 & -0.11 \\
\hline $\mathrm{NO}_{3}$ & 0.97 & 17 & 0.18 & 0.90 & 99.3 & 0.31 & -0.07 & 0.09 & 0.93 & -0.03 & 0.01 \\
\hline $\mathrm{pH}$ & 0.58 & 18 & 0.13 & 0.60 & 99.9 & -0.38 & 0.51 & 0.33 & -0.07 & -0.10 & -0.23 \\
\hline $\mathrm{Si}$ & 0.69 & 19 & & & & 0.05 & 0.00 & -0.82 & -0.09 & 0.03 & -0.05 \\
\hline $\mathrm{SO}_{4}$ & 0.84 & 20 & & & & 0.88 & 0.01 & -0.23 & 0.04 & 0.11 & -0.06 \\
\hline TDS & 0.77 & 21 & & & & 0.85 & 0.05 & 0.09 & 0.09 & 0.14 & 0.03 \\
\hline
\end{tabular}

Significant factor loadings with more than 0.50 are given in bold

increase in the concentration of $\mathrm{Cr}(\mathrm{VI})$ gradually decreases the concentration of $\mathrm{Ni}$ in groundwater.

The results show that six factors account for $75 \%$ of the variance in the data (Table 6). The trivalent, hexavalent and total $\mathrm{Cr}$ concentrations in groundwater during winter are loaded on factor 2, which describes $14.2 \%$ of the variance. The $\mathrm{pH}$ has positive loading and $\mathrm{Fe}$ has negative loading on this factor. The high positive factor loading of hexavalent $\mathrm{Cr}$ (0.8806) when compared to trivalent (0.6863) form indicates that the contribution of $\mathrm{Cr}(\mathrm{VI})$ to total $\mathrm{Cr}$ is more during winter season and is controlled by the $\mathrm{pH}$ in groundwater. The influence of $\mathrm{Fe}$ is negative during this season.

\section{Conclusions}

The following conclusions have been drawn from principle component and R-mode factor analysis: (1) At least four factors control the groundwater chemistry of the study area. (2) The association between trivalent, hexavalent and total $\mathrm{Cr}$ suggests that most of the $\mathrm{Cr}$ during summer is trivalent and that during winter is hexavalent. The hexavalent chromium is more mobile than trivalent in biological system and hence affects human health, particularly the kidney, if consumed beyond the permissible levels for a longer time. They are classified under the category of carcinogenic elements by WHO, and their excess use is capable of altering epidemiological cycle of human beings. Reports and interactions with people in the study area have shown prevalence of cancer among elders compared with surrounding regions (Periakali 1995; Satyanarayanan and Periakali 2004). The incompatibility of $\mathrm{Cr}$ with major elements suggests that the $\mathrm{Cr}$ species are mainly derived from mining wastes. (3) The major ions $\mathrm{Mg}, \mathrm{Na}, \mathrm{Cl}$ and $\mathrm{SO}_{4}$ in water are derived from the country rock including the mining waste due to dissolution of minerals, thereby altering the quality of groundwater.

Open Access This article is distributed under the terms of the Creative Commons Attribution 4.0 International License (http:// creativecommons.org/licenses/by/4.0/), which permits unrestricted use, distribution, and reproduction in any medium, provided you give appropriate credit to the original author(s) and the source, provide a link to the Creative Commons license, and indicate if changes were made.

\section{References}

Agterberg FP (1974) Geomathematics-mathematical background and geo-science applications, developments in geomathematics-I. Elsevier Scientific Publishing Company, Amsterdam, pp 1-596

APHA (1995) Standard methods for the examination of water and wastewater, 19th edn. American Public Health Association, Washington, pp 1-467 
Ballukraya PN, Ravi R (1999) Characterisation of groundwater in the unconfined aquifers of Chennai city, India: part 2-factor analysis. J Geol Soc India 54:13-22

Berner EK, Berner RA (1987) The global water cycle, geochemistry and environment. Prentice-hall, Upper Saddle River, pp 1-453

Briz-Kishore BH, Murali G (1992) Factor analysis for revealing hydrogeochemical characteristics of watershed. Environ Geol 19:3-9

Cain D, Helsel DR, Ragone SE (1989) Preliminary evaluation of regional groundwater quality in relation to land use. Groundwater 27:230-244

Cooper GRC (2002) Oxidation and toxicity of chromium in ultramafic soils in Zimbabwe. Appl Geochem 17:981-986

Davis JC (2002) Statistics and data analysis in Geology, 3rd edn. Wiley, New York, p 656. ISBN 978-0-471-17275-8

Dhakate R, Singh VS, Hodlur GK (2008) Impact assessment of chromite mining on groundwater through simulation modeling study in Sukinda chromite mining area, Orissa, India. J Hazard Mater 160:535-547

Dhal B, Das NN, Pandey BD, Thatoi HN (2011) Environmental quality of the Boula-Nuasahi chromite mine area in india. Mine Water Environ 30:191-196

Edmunds WM, Smedley PL (1996) Groundwater chemistry and health: an overview. In: Appleton JD, Fuge R, McCall GJH (eds) Environmental geochemistry and health, Geological Society London Special Publication no. 113, pp 91-105

Einax JW, Zwanziger HW, Geı $\beta$ S (1997). Chemometrics in environmental analysis. $\mathrm{VCH}$ verlagsgesellschaft $\mathrm{mbh}$, D-69451, Weinheim (Germany), pp 1-384

Frengstad B, Banks D, Siewers U (2001) The chemistry of Norwegian groundwaters: IV. The $\mathrm{pH}$-dependence of element concentrations in crystalline bedrock groundwaters. Sci Total Environ 277:101-117

Godgul G, Sahu KC (1995) Chromium contamination from chromite mine. Environ Geol 25:251-257

Henry JM, Shwartz FW (1990) The chemical evolution of ground water in the Milk river aquifer, Canada. Groundwater 28:253-261

Jackson ML (1967) Soil chemical analysis. Prentice-Hall of India Pvt. Ltd., New Delhi, pp 1-498

Kalaiselvan A (1994) Petrology and geochemistry of ultramafic rocks of northern Tamil Nadu, Southern India. Unpublished Ph.D. thesis, University of Madras, Chennai, India, pp 1-145

Kar D, Dur P, Mandal SK, Sahu T, Kole RK (2008) Assessment of heavy metal pollution in surface water. Int J Environ Sci Technol 5:119-124

Krauskopf KB (1979) Introduction to geochemistry. McGraw-Hill International Services, Singapore, pp 1-617

Krishna AK, Satyanarayanan M, Govil PK (2009) Assessment of heavy metal pollution in water using multivariate statistical techniques in an industrial area: a case study from Patancheru, Medak District, Andhra Pradesh, India. J Hazard Mater 167:366-373

Kumar PJS (2014) Evolution of groundwater chemistry in and around Vaniyambadi industrial area: differentiating the natural and anthropogenic sources of contamination. Chem Erde 74:641-651

Kutty TRN, Murthy SRN, Anantha Iyer GV (1986) REE geochemistry and petrogenesis of ultramafic rocks of Chalk Hills, Salem. J Geol Soc India 28:449-466

Lado LR, Sun G, Berg M, Zhang Q, Xue H, Zheng Q, Johnson CA (2013) Groundwater arsenic contamination throughout China. Science 341:866-868

Lawrence FW, Upchurch SB (1982) Identification of recharge areas using geochemical factor analysis. Groundwater 20:680-687
Li S, Zhang Q (2010) Spatial characterization of dissolved trace elements and heavy metals in the upper Han River (China) using multivariate statistical techniques. J Hazard Mater 176:579-588

Machiwal D, Jha MK (2015) Identifying sources of groundwater contamination in a hard-rock aquifer system using multivariate statistical analyses and GIS-based geostatistical modeling techniques. J Hydrol Reg Stud 4:80-110

Melloul A, Collin M (1992) The principle component statistical method as a complementary approach to geochemical methods on water quality factor identification: application to coastal plain aquifer of Israel. J Hydrol 140:49-73

Michael HA (2013) An arsenic forecast for China. Science 341:852-853

Moncur MC, Ptacek CJ, Blowes DW, Jambor JL (2005) Release, transport, and attenuation of metals from an old tailings impoundment. Appl Geochem 20:639-659

Peddorson JK, Bjerg P, Christman TH (1991) Correlation of nitrate profiles with groundwater and sediment characteristics in a shallow sandy aquifer. J Hydrol 124:263-277

Periakali P (1982) The geochemistry of ultrabasic suite of rocks of Nagaramalai, Salem District, Tamil Nadu, Ph.D. theis, University of Madras, pp 1-96

Periakali P (1995) Studies on the impact of carcinogenic trace elements geochemistry in ground water of magnesite mine area in and around Chalk Hills, Salem town, Salem district, Tamil Nadu with special reference to their effect on human health. Project report, University Grants Commission, New Delhi

Periakali P, Satyanarayanan M, Subramanian S (1999) Geochemical distribution of carcinogenic trace elements in magnesite mine area, Salem, Tamil Nadu. J Appl Geochem 1:41-51

Raymahashay BC (1996) Geochemistry for hydrogeologists. Allied Publishers Limited, New Delhi, pp 1-190

Reddy BM, Janardhan AS, Peucat JJ (1995) Geochemistry, age and origin of alkaline and ultramafic rocks of Salem, Tamil Nadu, South India. J Geol Soc India 45:1-12

Reimann C, de Caritat P (1998) Chemical elements in the environment. Factsheets for the geochemist and environmental scientist. Springer, New York, p 398

Satyanarayanan M, Periakali P (2002) Hydrogeochemistry and quality assessment of groundwater in and around Salem Magnesite Mine Area, Salem District, Tamil Nadu. Proceedings of the IGC on Sustainable development and management of groundwater resources in semi-arid region with special reference to hard rocks. In: Thangaran M, Rai SN, Singh VS (eds). IGC-2002, Dindigul, Tamil Nadu, India. A.A.Balkema Publishers, ISBN 90-5809-263-1: 197-210

Satyanarayanan M, Periakali P (2003) Geochemistry of groundwater over Salem ultrabasic-Peninsular gneissic rocks, Salem district, Tamil Nadu. J Geol Soc India 62:63-73

Satyanarayanan M, Periakali P (2004) Geochemistry of chromium in magnesite mining zones of Salem, Tamil Nadu and its impact on human health. Proceedings of workshop on medical geology (IGCP-454), Geological Survey of India, Nagpur, pp 397-404

Scanlon BR (1989) Physical control on hydrochemical variability in the inner blue grass karst region of central Kentucky. Groundwater 27:639-646

Scanlon BR (1990) Relationship between groundwater contamination and major ion chemistry in a karst aquifer. J Hydrol 119:271-291

SPSS (Statistical Package for Social Sciences) (1995) Professional Statistics 6.1 Marija J. Norusis/SPSS Inc., Chicago, IL, pp 1-385

Steube C, Richter S, Griebler C (2009) First attempts towards an integrative concept for the ecological assessment of groundwater ecosystems. Hydrogeol J 17(1):23-35 
Subburaj A (2008) District groundwater brochure, Salem District, Tamil Nadu. CGWB Technical report series, Ministry of water resources, Government of India, p 23

Subramanian KS, Selvan TA (2001) Geology of Tamilnadu and Pondicherry. Geol Soc India, Bangalore, p 192. ISBN 81-8586747-X

Tao L, Liu G, Liu X, Zhang C, Cheng D, Wang A, Li R (2014) Trace metal pollution in a Le'an River tributary affected by non- ferrous metal mining activities in Jiangxi Province, China. Chem Ecol 30(3):233-244

Viswanathan S, Nagendra Kumar P (1982) Charnockite and the associated ultramafic rocks around Shevaroy hills, Salem district, Tamilnadu. Quart J Geol Min Met Soc India 54:36-44

Windley BF, Selvan TA (1975) Anorthosites and associated rocks of Tamilnadu, southern India. J Geol Soc India 16:209-215 